\title{
The Movement of Power among the Actors Involved in the Process of Countering Hegemony on Indonesian Positive Law
}

\author{
S. Andika Cahya Ari Wibowo, Dwi Rukmini, Januarius Mujiyanto, \\ Abdurrachman Faridi
}

Language Education Doctoral Program, State University of Semarang, Semarang, Indonesia

\begin{abstract}
This study takes three law cases in Indonesia conflicting the powerful and the powerless as the subject of the study. In those cases all the suspects attempted to do counter hegemony to set them free. They employed sympathy as their counter-hegemonic device. Through employing sympathy they successfully break the positive law and gain their freedom. Hence, they succeeded to end the law hegemony which is attempted to exercise upon them. It is very likely that a successful counter hegemony will end in a new born hegemon. It is interesting to find out the possible movement of power among this old hegemon and the new one. Thus, this study is intended to explain this movement among those actors involved in the process of countering hegemony on positive law.
\end{abstract}

Keywords-Counter Hegemony on Indonesian Positive Law, Hegemony as movement of power, Positive Law as a form of Hegemony.

\section{INTRODUCTION}

The study is conducted within the inquiry area of three specified law cases: 1) Prita Mulyasari Case in 2008; 2) Minah's Cocoa Beans Stealing Case in 2009; and 3) The case of 'bullying' by Muhammad Arsyad, a satay seller, against President Joko 'Jokowi' Widodo in 2014. Those three cases portray the subordinate strategy to counter the hegemony on Indonesian positive law. Proven to be against the law those three subordinate parties might gain liberty by gaining the public sympathy.

This study interprets law as hegemony. Hegemony is performed through the implementation of constitution and government regulation. Regulation and constitution itself is basically an essence of ideas of the powerfull. This tends to be sensitively influenced by their interests. The possibility of hegemony on law has been stressed by Litowitz (2000, p.515). He argues that the current legal system is hegemonic in the Gramscian sense in that it induces people to comply with a dominant set of practices and institutions without the threat of physical force and that this hegemony is overarching because it encompasses people of diverse races, classes, and genders.

Those suspects' action to be against the law for their own benefit means that they have done counter hegemony on Indonesian positive law. Their success of doing this counters hegemony action by using the sympathy device had been studied by Wibowo (2020).

He found that three cases under the study were basically indicated as a counter hegemony to the government ideology; the view of positive law. In those three cases under the study, the government fails to hegemonize the suspects. Although they were strongly indicated to violate the law, they succeeded to gain freedom. They abused the sympathy by making its appeal as their strategy. As its theory, the fundamental aim of the counter hegemonic strategy was to foster great change in condition and ways of belief. His analyses results of both the appraisal devices and the ideology showed that through making appeal for sympathy they could free themselves from the established law. Their strategy was effective to foster great change in the view of law. Their freedom was evidence that law enforcers have already accepted and applied a new law approach in addition to the view of positive law. They succeeded to negate the hegemony of the view of positive law. He finally concluded that the sympathy appeal, which was basically an abuse of sympathy, was effective to use as strategy to counter hegemony on positive law in the law cases. 
Through abusing the sympathy, the suspects succeed to change the view of Indonesian positive law which stated that a person who had violated the law must be given punishment. In those cases, they succeed to gain freedom and avoid the sentence. They clearly negated the hegemony on Indonesian positive law. Hence, this counterhegemonic device was able to make the hegemon (the existing law and its law enforcers) fulfilled the demand of the suspects. It was able to help the suspects gaining their freedom.

The study is interested in identifying the movement of power among the actors involved in the process of countering hegemony on Indonesian Positive Law. The study provides model for identifying the power movement in a counter hegemony on law. It is further expected to provide awareness for the subordinate on the potency of power they possessed which may be used to negotiate their interest during the interaction with the powerful.

\section{THE LAW CASES UNDER THE STUDY}

The first case study is about the arrest of Prita Mulyasari, an ordinary 32-year-old mother of two, for allegedly defaming a hospital via an online complaint, triggered unprecedented public protest and thrust Indonesia's treatment of basic human rights back into the spotlight. The controversy surrounding her detainment led to the House of Representatives' demanding the hospital withdraw its accusations and saw the three current presidential candidates weighing in on the debate and eventually led to Prita being acquitted of all charges and her prosecutors facing investigation.

After receiving poor treatment at Omni International Hospital, Prita wrote an email on $15^{\text {th }}$ August 2008 detailing her experience to customer_care@banksinarmas.com and friends, which was soon rapidly distributed across forums via online mailing lists. On $30^{\text {th }}$ August again she sent the email to $\underline{\text { Surat }}$ Pembaca Detik.com. Once the email became public knowledge, Omni International Hospital responded by filing a criminal complaint and a civil lawsuit against Prita. On $11^{\text {th }}$ May 2009 the Tangerang District Court won the Omni Hospital Civil Claim. Prita was proven to have committed a legal act which harmed Omni Hospital. Prita was sentenced to pay a material loss of 161 million rupiahs as a substitute for clarification money in national newspapers and 100 million rupiahs for immaterial losses. Prita immediately appealed. She was then arrested on May $13^{\text {th }}, 2009$. She was also charged under Articles 310 and 311 of the Criminal Code regarding defamation and Decree
No. 11 of 2008 concerning Information and Electronic Transactions article 27. Prita faced a maximum six years imprisonment and fines of up to IDR 1 billion as a result of a sending this straight forward email of complaint.

Once the case generated massive public attention, the Tangerang district court which handles Prita case, began to feel the pressure. Rallies were held across the country by those who empathised with this normal, everyday mother suddenly behind bars away from her children. Civil movements, demanding reforms of the ITE Law and calling for the protection of consumers and freedom of expression, gathered speed and soon academics, politicians, international and local rights' activists, internet advocates and the public were joining the fray.

On $3^{\text {rd }}$ June 2009 Megawati and Jusuf Kalla visited Prita in prison. Then, Prita is released and can reunite with her family. His status was changed to city custody. However, she still obliged to pay the material and immaterial loss. Prita then filed an appeal to the Banten High Court because she does not feel that she has an obligation to pay compensation to the Omni International Hospital. The Banten High Court remained to impose a compensation of 250 million rupiahs. Prita then appealed to Supreme Court. Commission III of the House of Representatives of the Republic of Indonesia requested the Supreme Court to cancel the lawsuits against Prita. On September $29^{\text {th }}$, 2010, the Supreme Court issued a verdict in which he had agreed to Prita's appeal, rejecting the verdict district court and high court (Judex Factie), and refused the Omni International Hospital's lawsuit.

Prita release cannot be concluded solely due to unfulfilled legal facts. Significant pressure outside the trial eventually influences the court decision. An irregularity occurs in the judge's decision. Syauqiya (2013) conducted study about juridical review on Prita and Omni International Hospital Case. Early suspected to violate Decree No. 11 of 2008 concerning Information and Electronic Transactions article 27, he found that the decision of the Tangerang District Court, the Banten High Court, up to the Supreme Court did not clearly state the suitability to the Decree. In conclusion he stated that the judges decide only based on interpretation.

The second case is the case of "bullying" by Muhammad Arsyad, a satay seller, against President Joko "Jokowi" Widodo. Even though the President has forgiven Arsyad for the incident, it appears that his legal problems are not yet over, though his detention was delayed. Arsyad alias Arsyad Assegaf, 24, was arrested for defaming President Jokowi, a crime punishable by up to 12 years of 
imprisonment. Police stated that apart from the primary charges under the 2008 Pornography Law, the suspect was also charged under articles 310 - 311 of the Criminal Code for defamation and libel. Arsyad was arrested at his parents' home in Kramat Jati, in East Jakarta, on Oct. 24, based on a report filed in July by Henry Yosodiningrat, an Indonesian Democratic Party of Struggle (PDI-P) lawmaker and a member of the party's legal team, when Jokowi, then the governor of Jakarta, was engaged in a campaign battle with Gerindra Party chairman Prabowo Subianto.

Arsyad was charged with defamation and spreading pornographic material, a violation of the 2008 Pornography Law, and could face 12 years in prison. The team reported a Facebook account registered under the name of Arsyad Assegaf that had posted a series of pornographic images with the faces of Jokowi and Indonesian Democratic Party of Struggle (PDI-P) chairwoman Megawati Soekarnoputri. Many have come to Arsyad's defense, saying that his prosecution would not bode well for freedom of speech under Jokowi's administration. Among those who have taken a stand against the arrest is Gerindra politician and deputy speaker of the House of Representatives, Fadli Zon. Fadli accompanied Mursidah to the National Police headquarters on Friday in an effort to bail out Arsyad. On November $3^{\text {rd }}$ 2014, Arsyad had been released by the National Police. They even escorted him home. Iriana Jokowi (the president's wife) and Fadli Zon also donated some money to him to run a business. His legal files had never arrived at the trial process.

The third case is the case of a grandmother of seven who was charged with stealing three pieces of cocoa fruit and subjected to 18 days of house arrest before being dragged to court to receive a suspended sentence. It refers to the case of Minah, 55, an illiterate grandmother from a small village near Banyumas in Central Java. Minah was confused that, after having returned the cocoa fruit to the plantation, owned by PT Rumput Sari Antan, and having apologized profusely, they still reported her to the police. She was charged under articles 362 of the Criminal Code for stealing. Again, once the massive public sympathy given, the trial judge decided that she proven to commit the crime and sentence her one moth and fifteen days without necessarily undergoing detention.

Juridical review on Minah case had been studied by Murdoko (2016) and Wibowo (2010). Murdoko explained that Minah was convincingly commiting the crime due to already fulfill the elements of article of stealing; Whoever: Minah, Take Something: taking three cocoas, In whole or In part: three cocoas, It belongs to ISSN: 2456-7620 someone else: that three cocoas taken from the plantation owned by PT. Rumpun Sari Antan (RSA) 4, By intention to own illegally: Minah intended to take the three cocoas that falling from the tree to be taken home and made them as seed. He also analysed that her release was basically influenced by external factors outside consideration of the legal facts.

In his study, Wibowo (2010) stated that Minah was found guilty of stealing three or kilograms cocoa because the elements in Article 362 of the Criminal Code had been fulfilled. Further, forgiveness reason and justification reason were also not found in the case of Minah. Therefore, after all the law elements were fulfilled, then the judge, in this case, could impose a sentence. It is a judge consideration based on the decree, what is in the decree is considered as the law and it ignores speculation (positivistic considerations). However, it was just because of the news from mass media and the swift of sympathy and support that continues to flow and a number of gender activists expressed their concerns and came to the Regional House of Representative (DPRD) to participate in providing moral support made the judges panel to consider humanitarian principles.

\section{POSITIVE LAW AS A FORM OF HEGEMONY}

Positive law emphasizes that law is created and annulled by acts of human being, thus being independent of morality (Kelsen, 2007, p. 114). Its norms tell how a certain behavior is ordered, commanded, prescribed, forbidden or permitted or authorized (Kelsen, 2002, pp. 5-6). Further, in strong sense it is an order of the powerful/ hegemon. It induces people to comply with a dominant set of practices and institutions without the threat of physical force. A violation upon the legal norms leads to sanction (Asshiddiqie \& Safa'at, 2006. P.47). One of its characteristics is that it prioritizes legal certainty over justice (Wignjosoebroto cited in Artadi, p.70, 2006). The principle of legal certainty is basically a guarantee that law must be carried out in a good or appropriate manner. Certainty is essentially the main objective of the law. If it has no certainty, it will lose its identity and meaning. If it has no identity anymore, it is no longer used as people's code of conduct. Its ultimate purpose of society order and certainty over justice as if confirms that it is basically a form of hegemony. Moreover, the possible existence of hegemony on law has also been stressed by Litowitz (2000, p.515). He argues that the current legal system is hegemonic and that this kind of hegemony is overarching because it encompasses people of diverse races, classes, and genders. 


\section{HEGEMONY AS MOVEMENT OF POWER}

The study approaches hegemony from the perspective of movement of power. Every individual has power. Power is perceived as something which is not just essentially possessed by institution and used oppressively against individual or group. Foucault argues that power is divergent and dynamic. It is not centralized and static (Lemke, 2000, p.4). It is more like something that acts and operates in a certain way. It is more a strategy than a possession. He sees it as coextensive with resistance; as a productive factor (Balan, 2010, p.56). It is a strategy to achieve their needs as well as to mitigate others forces. The effectiveness of this power thus, depends on the individuals' ability to maintain it. According to Eriyanto (2001) as quoted by Oktavianti, the importance of power in a discourse is to see what is meant by control (p.12). One person or one group controls another person or group. Here, control does not necessarily mean a physical one but it may be in the form of mental or psychical. The dominant group may make the other groups talk and act based on their order.

This approach enables to elucidate the complexity of hegemony. It views hegemony as not simply the exercising of power from the powerful to the powerless. It opens alternating view for the powerless to resist the hegemony. This approach examines the relationship between power and those who exercise it, objected to it or make it possible.

Antoniades (2008) distinguished this type of hegemony into four different movements of power. First is 'Outside-Out'. Hegemony is conceptualized as the possession of overwhelming power (in terms of material capabilities) and the instrumental use of this power to secure leadership or dominance in world politics. It employs a 'conventional', top-down and 'agential' approach to hegemony. In this movement, power is interpreted as the ability of A to get B to do something he would not otherwise do it. Coercion becomes its characteristic. Hegemony is the hegemon's period of rule as well as the infrastructure created by this rule, and this period/ infrastructure ends/ collapses with the decline and collapse of the hegemon.

Second is 'Outside-In'. Hegemony is conceptualized as a specific strategy aiming at generating shared beliefs and a commonsense. The aim is to achieve leadership or dominance on the basis of consent rather than coercion. Similarly to the outside-out, this movement of power employs top-down use of power by one of these actors (the hegemonic power) over the others. This type of hegemony targets the very self-understanding of its audience. Power aims at the 'inside' of its target-audience. It is interpreted as the ability to affect peoples/ actors preferences and beliefs. Hegemony is about consent, shared values, preferences and beliefs, in one word, about identity.

It is an ability to make the various players existing within the hegemonic order keeps their faith in the set of beliefs, preferences, values and ideas exposed by the hegemon. Consequently, hegemony collapses when those players (or the majority or the most influential among them) stop to believe in and defend these values, and therefore the hegemon has to turn back to threats, promises or violence in order to enforce its will. The failure is accompanied by the rise of counter hegemonic projects that come to provide new values, a new commonsense, a new hegemony.

The third is 'Inside-Out'. Hegemony is conceptualized as a sociocultural project aiming to generate imitation within world politics, while assuming the existence/ possibility of different socio-cultural projects and ways of being. The boundary between the outside-in approach and the insideout is thin and somewhat blurred. Both approaches characterized by consent, personal values and beliefs. The difference lied on the outside-in approach has a clear set of actors (the hegemon and its 'target audience') and a use of power by one actor (the hegemon) over the others. In contrast, there is no clear pair of actors. Hegemony is conceptualized in a way of a community that projects its values to its outer environment, inviting different people/actors to join or follow/ imitate its way of being. Systemic hegemons invite the audience through attraction. They captivate them by presenting their attracting sociocultural values. Thus, systemic hegemons do not approach the audience actively; rather, the captivated audience approaches them. Further, this type of hegemony is able to co-exist in harmony in a system with multiple and diverse commonsense.

The last type of this movement of power is 'Inside-In'. Hegemony is interpreted as a bottom-up movement of power. It is conceptualized as a diffused and decentred apparatus of (bio) power aiming at the control and governing of human life from its interior. It is the ultimate type of hegemony. It makes the subject/ audience capable of controlling and/ or to regulating his own freedom. The hegemony values originate from his own commonsense and thus, become an integral part of his life. The subjects/ audiences do not feel being under hegemony. Under the influence of this type of hegemony, the subjects tend to feel that they cannot live beyond hegemony (p. 8 15). However, hegemony is not understood as constant. Change in the nature of hegemony is possible, through 
resistance at the level of everyday life. Further, Consent is never total or seamless (Caroll, 2010).

No hegemony is constant due to the dynamic nature of power. A countering, change and resistance is very likely to happen. It may be in a form of offensive expression, disobedience, contesting and opposing ideas and values, boycott, even to the extreme of physical confrontation.

\section{COUNTER HEGEMONY ON INDONESIAN POSITIVE LAW}

Counter-hegemony points to a strong degree of resistance that involves the coordination of people, groups and interests with the intention of shifting hegemonic power relations. Considering the law cases under investigation, it evidences that the actors who commit the crime successfully set themselves free from lawsuits. It is suspected that they manipulate sympathy as a strategy to gain freedom. Hence, they successfully do counterhegemony on positive law; in the perspective of positive law. Gramsci in Zembylas (2013) emphasizes that counter hegemony is essentially moral and intellectual process that challenge normative view (based on legal norms). It targets great change in condition and ways of belief. Thus considering Gramsci's definition and Foucault ideas upon the divergent and dynamic characteristics of power as an essential element of hegemony, the study attempts to define counter hegemony as the shifting of power movement from the usual superordinate-to-subordinate group to the unusual subordinate-to-superordinate group which targets great change in condition and ways of belief.

Indonesia adheres to positive law view (Wahyuni, 2012; Sudiyana \& Suswoto, 2018; Amin, 2013). It is stated that the one who convincingly, according to legal facts, commits the crime must be sentenced. It indicates that the suspects in the law cases under the study successfully challenged this view. Moreover, Indonesian Criminal Code (KUHP), as a manifestation of the view of positive law, in the second verse mentions that criminal provisions in Indonesian legislation are applied to everyone who committed crime in Indonesia. Those actors ability to break this verse may indicate their counter-hegemony.

\section{RESEARCH METHODOLOGY}

The study attempts to identify the movement of power among the actors involved in the process of countering hegemony on Indonesian Positive Law. In such interaction, people tend to bring their own interest. Often they speak what they do not want to do and vice versa. In this case, we should not take the existing meaning as it is. Rather, we need to go beyond what is being stated. Certainly, analyzing what is beyond stated becomes the field of Critical Discourse Analysis (CDA). It facilitates the meaning understanding. It possibly happens as the validity of the surrounding information is out of assurance. Further, meaning is not a monolithic construct. It is a multidimensional and slippery concept with amazing complexity (Ahmadvand, 2008, p.1). CDA is believed to own potential to address such problem. Van Dijk (2009) stated that CDA can take its place to identify problems that occur in a text. It aims to uncover the hidden meaning in the text. It works beyond the explicit. CDA also provides a tool for deconstructing the ideologies of the mass media for identifying social, economic and power relations between dominant and subordinate groups (Henry \& Tator, 2002).

Further, the study also integrates Appraisal System Analysis. It is a practical analysis tool to provide raw linguistic evidence for further stage analysis. There is a need to formulate practical tool. The first dimension to conduct the analysis of a discursive event is textual analysis. At this stage the study employs appraisal system analysis. First, it is intended to provide raw linguistics evidence for further stage analysis. The study tries to reduce the sense of subjectivity by providing linguistic evidences since the notion of subjectivity to what extent has been identical to CDA. Secondly, it is selected as it also enables the study to go beyond the explicit. White (2001) argues that the term Appraisal is used to cover-all terms to encompass all evaluative uses of language, including those by which speakers/writers adopt particular value positions or stances and by which either actual or potential respondents.

\section{RESULT AND DISCUSSION}

In the law cases under the study, the previous form of hegemony is hegemony on positive law. The actors involved in this form of hegemony are the hegemon and its "target audience". In those cases, the disputing parties are Prita Mulyasari against Omni Hospital, Minah against RSA Ltd, and Arsyad against Jokowi. However, as the cases have been brought into the realm of law, then the dispute also occurs between Prita, Minah and Arsyad (the suspects) against the ITE law which is basically the realization of positive law.

Both of the results of appraisal devices analysis and ideology analysis reveal that through abusing sympathy indicate the redefinition of the hegemony's actors. The suspect changes role to be the hegemon while the view of positive law, the law enforcers, press and 
public become the audiences. Moreover, through their strategy, they succeed to shift the conventional movement of power from the law enforcers and the view of positive law (the hegemon) to the suspects (its target audience) to the unconventional movement from the suspects (the hegemon) to the law enforcers and the view of positive law (its target audience).

As stated in its theory, counter hegemony is defined as great change in condition and ways of belief. It is very likely that in every successful counter hegemony there will be a newborn hegemon. This new hegemon brings new ways of belief and creates new condition of life. Further, the emergence of this hegemon also reflects the shifting movement of power. This power movement shifts from the usual superordinate to subordinate group to unusual subordinate to superordinate one. It is caused by the successful implementation of the subordinate strategy of counter- hegemony.

In the law cases under the study, the previous form of hegemony is hegemony on positive law. The actors involved in this form of hegemony are the hegemon and its "target audience". In those cases, the disputing parties are Prita Mulyasari against Omni Hospital, Minah against RSA Ltd, and Arsyad against Jokowi. However, as the cases have been brought into the realm of law, then the dispute also occurs between Prita, Minah and Arsyad (the suspects) against the ITE law which is basically the realization of positive law. This is basically the real dispute as they want to escape from the entanglement of the charged law. Moreover, the charged law is basically the government product. They through law enforcers have an interest in creating this product as means of hegemony to create society order. Hence, in this hegemony on positive law it may be identified that the hegemon is the law enforcers as the representation of government and the positive law (the ITE law), while its target audience is clearly the suspects. This hegemony refers to Antoniades' Outside-Out hegemony (2008). It is a type of 'conventional', top-down hegemony in which the power moves conventionally from hegemon (the law enforcers and the positive law) to its target audience (the suspects).

Both of the results of appraisal devices analysis and ideology analysis reveal that through abusing sympathy the suspects may free themselves from the entanglement of law; from the hegemony on positive law. They counter the hegemony through the strategy of sympathy abuse. They negate the hegemony conducted by the positive law and the law enforcers. Their freedom evidences the despair of hegemon. They also succeed in forcing the public and press to support them. By the help of public and press, they force the hegemon to grant their ISSN: 2456-7620 wishes. They make the view of positive law meaningless and have no function. They make the law enforcers to issue the trial verdict which benefit them; thus to give them freedom. At this point they even hegemonize the hegemon back.

The hegemony's actors are then redefined. The suspect changes role to be the hegemon while the view of positive law, the law enforcers, press and public become the audiences. Moreover, through their strategy, they succeed to shift the conventional movement of power from the law enforcers and the view of positive law (the hegemon) to the suspects (its target audience) to the unconventional movement from the suspects (the hegemon) to the law enforcers and the view of positive law (its target audience). However, this form of hegemony is certainly different from the hegemony on positive law. It slightly takes the second form of Antoniades' hegemony which is 'Outside-In' (2008). It is conceptualized as a specific strategy aiming at generating shared beliefs and a commonsense. It is also characterized by the absence of coercion. In addition, the power of this type of hegemony aims at the 'inside' of its target-audience. It is interpreted as the ability to affect people/ actors preferences and beliefs. All of these features are already reflected in their form of hegemony.

From the beginning of these cases until then the suspects succeed to gain the freedom, they never employ coercion. The suspects attempt to exploit the audiences' sympathy to accept their belief and to ignore their own commonsense. Through sympathy abuse, it indeed aims at the 'very inside' of the law enforcers, public, and press. It targets and exploits their emotion. It also turns out to be able to affect the public and press to accept their belief. It is even able to affect the law enforcers to ignore their idealism about the view of positive law which in turn give them freedom. It means that law enforcers have accepted and applied a new law perspective besides the view of positive law. Those evidence the existing of the new form of hegemony.

\section{CONCLUSION}

The previous form of hegemony in the law cases under the study is hegemony on law. The actors involved in this form of hegemony are the hegemon and its "target audience". In those cases, the disputing parties are Prita Mulyasari against Omni Hospital, Minah against RSA Ltd, and Arsyad against Jokowi. However, as the cases have been brought into the realm of law, then the dispute also occurs between Prita, Minah and Arsyad (the suspects) against the ITE law which is basically the realization of positive law. 
The hegemony's actors are then redefined. The suspect changes role to be the hegemon while the positive law, the law enforcers, press and public become the audiences. Moreover, through their strategy, they succeed to shift the conventional movement of power from the law enforcers and the positive law (the hegemon) to the suspects (its target audience) to the unconventional movement from the suspects (the hegemon) to the law enforcers and the view of positive law (its target audience).

The analysis of the movement of power among the actors involved in the process of countering hegemony is essentially intended to stress as well as to confirm the success of the counter hegemonic action done by the suspects on the Indonesian positive law. Moreover, this finding offers new insight as well as description that they have been aware of the potential power they have as well as its effective device (sympathy) to actualize their power in negating possible agenda of the powerful. The study has limited generalisability owing to the fact that the issue discussed evolves from three law cases. Richer analysis of a larger sample of cases would widen the scope and increase the generalisability of the findings of a study.

\section{REFERENCES}

[1] Ahmadvand, M. 2008. Critical Discourse Analysis: An Introduction to Major Approaches. http://www.iranian linguistics.org/papers/ Critical DiscourseAnalysis.pdf.

[2] Amin, H. 2013. Reformulasi Hukum Positif di Indonesia. Panel Paper on the $3^{\text {rd }}$ National Conference of the Indonesian Philosophy of Law Association.

[3] Antoniades, A. 2008. From 'Theories of Hegemony' to 'Hegemony Analysis' In International Relations. http://sro.sussex.ac.uk.

[4] Artadi, I. 2006. Hukum: Antara Nilai-Nilai Kepastian, Kemanfaatan dan Keadilan. Jurnal Hukum dan Dinamika Masyarakat Edisi Oktober, 67-80

[5] Asshiddiqie, J. \& M. Ali S. 2006. Teori Hans Kelsen tentang Hukum. Jakarta: Sekretariat Jenderal dan Kepaniteraan Mahkamah Konstitusi RI.

[6] Balan, S. 1999. M. Foucault's View on Power Relations. http://cogito. ucdc.ro.

[7] Criminal Code (KUHP) of Republic Indonesia.

[8] Dijk, T.A. van. 2009. Society and Discourse: How Social Contexts Influence Text and Talk. New York: Cambridge University Press.

[9] Henry, F. \& Carol T. 2002. Discourses of Domination: Racial Bias in the Canadian English-Language Press. Toronto: University of Toronto Press.

[10] Kelsen, H. 2002. Pure Theory of Law. Union, New Jersey: The Lawbook Exchange, Ltd.

[11] Kelsen, H. 2007. General Theory of Law and State. Clark, New Jersey: The Lawbook Exchange, Ltd.
[12] Lemke, T. 2000. Foucault, Governmentality, and Critique. http:// www. Thomas lemke web.de/ publikationen/Foucault.

[13] Litowitz, D. 2000. Gramsci, Hegemony, and the Law https://digitalcommons.law.byu.edu/lawreview/vol2000/iss2/ 1.

[14] Murdoko. 2016. Disparitas Penegakan Hukum di Indonesia (Critical Analysis of Minah's Case in the Perspective of Progressive Law). https://www.ojs.hang tuah.ac.id/ojs.

[15] Oktavianti, I. N. 2008. A Comparative Study of Language, Power and Ideology In Insert InvestigasiAnd Silet Infotainment Programs A Study of Critical Discourse Analysis. A Thesis. Brawijaya University. http://www.scribd.com/

[16] Sudiyana \& Suswoto. 2018. Kajian Kritis terhadap Teori Positivisme Hukum dalam Mencari Keadilan Substantif. Jurnal Ilmiah Ilmu Hukum QISTIE Vol. 11. No. 1, 107 - 136

[17] Syauqiya, R. H. 2013. Kasus Prita dan $R S$ Omni Internasional.https://www.Prita/PTIK.futsukaa.htm.

[18] Wahyuni, S. 2012. Pengaruh Positivisme dalam Perkembangan Ilmu Hukum dan Pembangunan Hukum Indonesia. Ejournal.uin.suka.ac.id.

[19] White, P.R. 2001. Appraisal: an Overview. http://www.grammatics.

[20] Wibowo, D. S. 2010. Analisis Studi Kasus Nenek Minah dalam Perkara Nomor 247/PID.B/2009/PN.PWT Sebuah Tinjauan Pembuktian Penerapan Hukum Positivistik dan Prinsip Kemanusiaan. A Final Project. UNS

[21] Wibowo, SACA. 2020. The Abuse of Sympathy to Counter Hegemony on Indonesian Positive Law. An Unpublished Dissertation. UNNES

[22] Zembylas, M. 2013. Revisiting the Gramscian Legacy on Counter-Hegemony, the Subaltern and Affectivity: Toward an 'Emotional Pedagogy' of Activism in Higher Education. Journal of Critical Studies in Teaching \& Learning, Volume: 1 Issue: 1, DOI: 10.14426/cristal. v1i1.2, 1-21. 